\title{
JUHÁSZ JUDIT
}

\section{A méltó emberi élet lehetősége}

\begin{abstract}
A képességszemlélet a fejlődésre az emberek lehetőségeinek bővüléseként tekint. Jelen tanulmány bemutatja a szemlélet főbb meglátásait, majd 40 mélyinterjú alapján megvizsgálja, hogy egy hazai nagyvárosban a helyi szegénységenyhítő tevékenységet végző csoportok hogyan tekintenek az érintettek lehetőségeinek bővítésére, milyen célokat, értékeket követnek. A cikk végül összegzi, hogy a tapasztalatok és az elméleti meglátások hogyan gazdagíthatják egymást. Az eredmények alapján a seni és nussbaumi megközelítésmód elméleti és gyakorlati összehangolása indokolt lehet a szegénységenyhítés folyamatában. Az emberi léthez szükséges univerzális lehetőségek biztosítása elősegítheti az érintettek képessé tételét arra, hogy hosszú távon méltó emberi életet élhessenek.*

Journal of Economic Literature (JEL) kód: A13, I30, I38, O15, O20.
\end{abstract}

Az elmúlt negyed évszázadban, különösen 2000 óta jelentős elörelépés mutatkozott globálisan az emberi fejlődés ${ }^{1}$ számos területén, többek között az extrém szegénység vagy az alultápláltság tekintetében. 1990-től 2015-ig a jelentős népességnövekedés ellenére több mint 1 milliárd embernek sikerült kikerülnie az extrém szegénységből, 2,1 milliárd ember egészségügyi hozzáférése javult, és több mint 2,6 milliárd ember jutott jobb minőségü ivóvízhez. ${ }^{2}$ A fejlődő régiókban az alultápláltak aránya 1990 óta majdnem megfeleződött. Számos emberi sors vált jobbá, ám nem mindenkié és nem ugyanolyan mértékben (UN [2015], UNDP [2017]).

\footnotetext{
* Köszönöm a kutatás résztvevőinek, hogy megbíztak bennem. Nagy köszönettel tartozom továbbá a tanulmány két lektorának és Tóth Gergőnek, akik részletes javaslataikkal segítették a cikk pontosítását, valamint közvetlen kollégáimnak, hogy az írás egy korábbi, hosszabb változatát véleményezték.

${ }^{1}$ A nemzetközi szakirodalomban elterjedt human development kifejezésre utalva.

${ }^{2}$ További adatok: http://blogs.worldbank.org/opendata/2017-atlas-sustainable-development-goalsnew-visual-guide-data-and-development?CID=ECR_FB_worldbank_EN_EXT; http://datatopics. worldbank.org/sdgatlas. A tanulmányban szereplő internetes hivatkozások utolsó letöltésének ideje 2018. október.
}

Juhász Judit közgazdász, az SZTE Gazdaságtudományi Kar Kutatóközpont tudományos segédmunkatársa (e-mail: judit.juhasz@eco.u-szeged.hu).

A kézirat első változata 2018. szeptember 9-én érkezett szerkesztőségünkbe.

DOI: http://dx.doi.org/10.18414/KSZ.2018.12.1299 
Globálisan a jelenben 632 millióan élnek mélyszegénységben, ${ }^{3}$ és minden tizedik másodpercben életét veszíti valaki éhezés vagy alultápláltság következtében. ${ }^{4}$ Magyarországon 2012-ben a súlyos anyagi deprivációban élők aránya 27,8 százalék volt, amit jelentős javulás követett, de 2017-ben ez a méröszám így is 14,5 százalék, a szegénység vagy társadalmi kirekesztődés kockázatának kitettek aránya pedig 25,6 százalék volt (Eurostat [2018]). Az elmúlt években Magyarországon a szociális biztonsághoz való jog alkotmányos szűkítése, a szegényellenes diskurzusok erősödése tapasztalható (Ferge [2008], Darvas [2015], Váradi [2015]). 2016. október 15. és 2017. március 1. között összesen 180 ember vesztette életét kihűlés miatt (Utcajogász [2018]). A szabálysértési törvény 2018. október 15-én hatályba lépett módosítása következtében következtében a hajléktalanságot szigorúan büntetik. ${ }^{5}$ A probléma tehát napjainkban is tetemes, rendszerszintü és hosszú távú, valódi megoldást igényel.

Az emberi fejlődésről szóló ENSZ-jelentés (Human Development Report) kiemeli az univerzalizmus jelentőségét. E szerint kivétel nélkül minden egyes ember számára elérhetővé kellene váljon, hogy az életében rejlő teljes lehetőséget megélhesse, kihasználhassa - most és a jövőben egyaránt. Az elsőként 1990-ben megjelenő, globális helyzetet bemutató jelentés inspirációját és alapját Amartya Sen közgazdaságtani megközelítése, a képességszemlélet (Capability Approach) jelenti (Robeyns [2006], UNDP [2010]). Ebben Sen a szegénységet az elérhető lehetőségek hiányaként, az emberi fejlödést pedig a lehetőségek bővüléseként határozza meg aszerint, hogy az egyének olyan életet élhessenek, amelyet okkal értékesnek tartanak (Sen [1999/2003]). Az egyik legfontosabb - jórészt megválaszolatlan - kérdés, amely a képességszemlélettel kapcsolatban felmerül, hogy ki és hogyan dönt arról, hogy az egyén milyen lehetőségei bővülhetnek, milyen is a jó élet az egyén számára, amelyet értékesnek tarthat (Nussbaum [1993], Sen [1999/2003], Alkire [2002]). A képességszemléletben két fö megközelítéssel találkozhatunk a lehetőségek bővítésének tekintetében. A szemlélet megalkotója, Amartya Sen megközelítése mellett Martha Nussbaum hozzájárulása is meghatározó a szemlélet fejlődésében.

A szegénységenyhítő folyamatok során az érintettek életében sokszor megjelenik közvetlenül vagy közvetetten egy másik, segítő fél is, egy egyén vagy csoport formájában. E szereplők különböző mértékben, de befolyásolhatják azt a folyamatot és irányt, amelyen keresztül az érintettek élete változik, lehetőségei alakulnak, bővülnek. E tanulmány bemutatja, hogyan jelenik meg a képességszemléletben a szegény társadalmi csoportok lehetőségeinek bővülése, majd megvizsgálja, hogy egy hazai nagyvárosban a helyi szegénységenyhítő tevékenységeket végző csoportok hogyan tekintenek az érintettek lehetőségeinek bővítésére, milyen célokat, értékeket, szemléletet, módszertant követnek a szegénységenyhítési folyamatok során. Ennek vizsgálatára kvalitatív, feltáró kutatást végeztem. 40 félig strukturált mélyinterjút folytattam le helyi segítő csoportok vezetőivel, alkalmazottaival, önkénteseivel, beleértve civil szervezeteket, informális civil szerveződéseket, önkormányzati, állami

\footnotetext{
${ }^{3}$ https://worldpoverty.io.

${ }^{4}$ http://poverty.com/index.html.

${ }^{5}$ http://www.parlament.hu/irom41/00708/00708.pdf.
} 
egységeket, egyházközségeket, segítő tevékenységet is folytató vállalkozásokat. Az empirikus eredmények alapján végül visszacsatolok a képességszemlélet meglátásaira, és összegzem, hogy a gyakorlati tapasztalatok és az elméleti meglátások hogyan gazdagíthatják egymást.

A szakirodalom nagy hangsúlyt fektet a képességszemlélet két fö megközelítésének tárgyalására, ám kevés tanulmány foglalkozik azzal, hogy az elméleti meglátások miképpen találkoznak a tapasztalatokkal, illetve hogy a terepi tapasztalatok hogyan gazdagítják a szegénységről kialakított elméleti koncepciókat. Az emberi fejlődést bemutató ENSZ-jelentés (UNDP [2017]) kiemeli, hogy egy dolog az elv, egy másik pedig a gyakorlat. Ez megkívánja néhány elemzési és értékelési folyamat központi kérdéseinek átalakítását a gyakorlatban. Ennek megfelelően kutatásom jelentősége abban áll, hogy hozzájárul a mindenki számára elérhető méltó emberi lét lehetővé tételéhez a gyakorlati tapasztalatok és az elméleti meglátások kölcsönös egymásra hatásának hangsúlyozásával és vizsgálatával. Jelen kutatás a jövőben elengedhetetlenül kiegészül az érintettekkel folytatott vizsgálattal.

\section{A szegénységről és a fejlődésről való gondolkodás a képességszemléletben}

Az 1980-as és a korai 1990-es években a képességszemlélet csupán az egyik versenyző megközelítésként volt jelen a fejlödés és egyenlötlenségek nemzetközi tárgyalási terében. Az elmúlt évtizedben azonban Amartya Sen képességszemlélete kiemelt figyelmet ért el az emberi jóllétről és fejlődésről gondolkodók körében, és mostanra a fóáramú közgazdasági keretek vezető alternatívájává vált (Robeyns [2006], Crocker [2008], Clark [2012b]). A képességszemlélet különböző interpretációi eligazítást jelentenek az egyéni jóllétet és a társadalmi berendezkedésünk alakítását érintő értékelési, tervezési folyamatokat illetően is (Stewart-Deneulin [2002], Clark [2005], Rauschmayer és szerzőtársai [2011]).

\section{A képességszemlélet alapfogalmai}

A képességszemlélet alapfogalmait (Sen [1993], [1995], [1999/2003]) és árnyalataikban eltérő értelmezéseiket a szakirodalom számos alkalommal tárgyalja (például: Alkire [2002], Clark [2005], Robeyns [2005], Crocker [2008], Rauschmayer és szerzötársai [2011], Qizilbash [2012], magyar nyelven: Gébert [2015], [2017]).

A képességszemléletben az emberi fejlődés (human development) az egyének lehetőségeinek bővítéséről szól, az emberek arra irányuló szabadságának kiterjesztéséről, amely hozzájárul ahhoz, hogy a bennük lévő lehetőségeket kihasználhassák, és olyan életet élhessenek, amelyet okkal értékesnek tartanak. E lehetőségek halmazára utal a képességek/lehetöségek (capabilities) fogalma, amely a számunkra rendelkezésre álló választható opciókat jelenti. E képességeknek/lehetőségeknek két alapvető aspektusa van, a jóllétünk (well-being) szabadsága és a saját ügyeink tevékeny elömozditására 
(agency) vonatkozó szabadságunk, amelyek találkozhatnak is egymással. A jóllét szabadsága a saját személyes előnyünkre váló lehetőségekre utal, míg az ügyeink előmozdításának szabadsága bármilyen fontosnak tartott célunk elérésére, annak befolyásolási lehetőségére vonatkozik.

A rendelkezésre álló lehetőségeinkből legtöbbször nem mindent valósítunk meg (hacsak nem nagyon szükös ez a halmaz). Különböző kombinációkat választhatunk a lehetőségeink halmazából, amelyeket valóban el szeretnénk érni, meg szeretnénk élni. Ezekre a választásokra utal a tevékenységek/állapotok (functionings) fogalma. Két embernek lehetnek hasonló lehetöségei, mégis megtörténhet, hogy különbözően választanak ezekből, és más típusú életet élnek; avagy különböző lehetőséghalmaz áll a rendelkezésükre, mégis azokból hasonló tevékenységeket/állapotokat választanak ki. Az egyén azoknak a lehetőségeknek is fontos szerepet tulajdoníthat, amelyekkel bár nem él, de rendelkezésére állnak, elérhetők a számára.

Lehetőségeink halmazának bősége és milyensége nagyban függ a számunkra rendelkezésre álló eszközöktől (means) és azoktól a belső vagy külső tulajdonságainktól, körülményeinktől, az úgynevezett átváltási tényezőktől (conversion factors), amelyek hozzásegítenek bennünket ahhoz, hogy az eszközeink felhasználásából célokat, tevékenységeket/állapotokat érjünk el. Olyan tevékenységeket/állapotokat, amelyeket a lehetőségeink közül választottunk, és valamilyen oknál fogva értékesnek tartunk magunk vagy mások számára.

\section{A képességszemlélet értékelési tere}

Arról, hogy az egyénnek vagy egy társadalomnak hogyan megy a sora, attól függően tudunk nyilatkozni, hogy mi alapján ítéljük ezt meg, milyen szempontok játszanak szerepet az értékelés folyamatában. E szempontok alkotják meg az értékelés terét, amely egyfajta meghatározottságot, információs korlátozást jelent (Sen [1993]). Azaz attól függően, hogy milyen ismérveknek van létjogosultsága bekerülni az értékelési térbe, bizonyos ismérveknek jelentőséget tulajdonítunk, míg mások háttérbe szorulhatnak vagy teljesen láthatatlanná válhatnak az értékelés folyamatában.

A képességszemléletben az egyén és a társadalom létének, müködésének értékelési alapját a képességek/lehetőségek tere jelenti. Ez a tér helyet ad számos olyan emberi képességnek/lehetőségnek, amelyek az egyének számára fontosak lehetnek. Az értékelés jövedelemnek, vagyonnak, különböző javaknak és erőforrásoknak önmagában nem tulajdonít értéket, ezek a változók nem tekinthetők az értékelési tér részének, bár közvetett módon befolyásolhatják az értékelést azzal, hogy hatással vannak a teret alkotó képességekre/lehetöségekre (Sen [1995]).

A releváns képességek/lehetőségek meghatározásának szükségessége köré épül a képességszemlélet egyik központi vitája. Sen szerint az egyének különbözők, céljaik eltérők, és eltérő tevékenységeket/állapotokat értékelhetnek. Fontosnak tartja az ezek közötti választás szabadságát, így nem bocsát rendelkezésre egy elöre meghatározott listát az univerzálisan érvényes képességekről/lehetőségekről (Sen [1993], [1999/2003], Crocker [2008]). Mások szerint azonban szükség van a morálisan helyesnek 
és helytelennek tartott képességek/lehetőségek elkülönítésére (Robeyns [2006]), aminek eredményeképpen számos kísérlet történt képesség/lehetőség listák megalkotására (Alkire-Black [1997], Nussbaum [2003], [2011], Robeyns [2006]).

A képességszemlélet és az emberi fejlődés elméletének szintén kiemelkedő hozzájárulója Martha Nussbaum, aki az emberi képességek/lehetőségek rögzítése mellett érvel, és ehhez nyújt is egy meghatározott listát, amely a következőkből épül fel (Nussbaum [2011]). ${ }^{6}$

1. ÉLET: egy emberi életnek megfelelö élethossz megélésének lehetősége.

2. Testi EGÉszsÉG: a jó egészség, jóltápláltság, megfelelő hajlék meglétének lehetősége.

3. Testi INTEGRITÁs: a test helyváltoztatásának lehetősége, fizikai biztonsága; a szexuális kielégülés és a reprodukciót érintő választások megtételének lehetősége.

4. ÉRZÉKEK, KÉPZELET ÉS GONDOLAT: az érzékek használatának lehetősége a képzelethez, gondolkodáshoz, érveléshez.

5. ÉRzELMEK: a másokhoz és más dolgokhoz való kötődés, a szeretet, szomorúság, vágyakozás, hála, az indokolt harag megélésének lehetősége.

6. Az ÉSZ HASZnÁlata a GYAKORLATban: az egyén képessége/lehetősége a jó fogalmának a kialakítására és az élet tervezésének elkötelezett, kritikai szemléletére.

7. Csoporthoz TARTOZÁs: képesség/lehetőség együtt élni másokkal, nyitottságot és érdeklődést mutatni más emberek iránt, képesség/lehetőség az önbecsülésre és az olyan élölényhez méltó bánásmódra, aki ugyanolyan értékes, mint mások.

8. MÁs FAJOK: képesség/lehetöség az állatokkal, növényekkel és a természettel közös, összeköttetésben álló életre.

9. JáTÉK: képesség/lehetőség a nevetésre, játékra, szórakozásra.

10. KÖRNYEZET FELETTI KONTROLL POLITIKAI ÉS ANYAGI ÉRTELEMBEN: a döntéshozatali folyamatokban történő hatékony részvétel, a szólásszabadság és az egyesülési szabadság biztosítása, az anyagi tulajdonjog, a munkavállalás, az emberhez méltó munkakörülmények lehetősége.

Nussbaum abban látja a kormányok feladatát, hogy attól függetlenül, hogy az embereknek milyen a jó életről való elképzelésük, támogassák ezt a belső értékeket tartalmazó normatív listát, és törekedjenek arra, hogy ezek a képességek/lehetőségek minden egyes ember számára elérhetők legyenek (Nussbaum [2006], Crocker [2008]). A nussbaumi képességek/lehetőségek az emberi létböl, méltóságból vezethetők le, függetlenül attól, hogy azokat a helyi hagyományok során a közösség felismerte-e, vagy sem (Nussbaum [1993]). Ám ez nem zárja ki az egyediség figyelembevételét. Nussbaum a listát elvontan fogalmazta meg, annak megvalósulását a helyi szintre bízza a lokális különbségek figyelembevétele mellett, így érzékeny marad a történelmi és kulturális különbségekre (Nussbaum [2006], Robeyns [2006]).

Nussbaum [2002], [2011] szerint bizonyos esetek kiemelten alátámasztják a rögzített lista szükségességét, és rávilágítanak arra, hogy az egyén és a közösség által

\footnotetext{
${ }^{6}$ Az egyes tételekhez tartozó képességeket/lehetöségeket a legtöbb esetben Nussbaum [2011] a leírtaknál részletesebben mutatja be.
} 
meghatározott célok nem mindig kedvezők a megalkotójuk és a társadalom számára. Néhány példa: Több más képességgel/lehetőséggel egyetemben a kegyetlenségre való nyitottság nem járul hozzá az emberi prosperitáshoz (Nussbaum [2002]). A komoly kognitív károsodást szenvedett egyének egyszerủen nem tudják felépíteni a jó életről alkotott elképzelésüket, nem számít, milyen intenzív az a támogatás, amelyet a társadalomtól kapnak (Crocker [2008]). Sen is érinti, hogy a szegénység esetén talán néhány képességet/lehetőséget, mint például a jóltápláltság állapota és a megfelelö hajlék megléte, kiemelten fontosnak tarthatunk (Sen [1993]). Néhány tradicionális és hegemonikus közösségben mélyen gyökerezhet a nők (vagy más csoportok) elnyomása, egyenlőtlensége. Ez azonban nem a dolgok természetéből adódik, hanem társas hagyományokon keresztül konstruált, így nem kell természetes jelenségként elfogadnunk (Nussbaum [2002]).

\section{Az értékelési tér feltöltése}

Sen szerint bármely értékelési gyakorlatnak (a képességek/lehetőségek meghatározásának) az egyén és a csoportok különbözö kontextusának, eltérő céljainak megfelelően közösségi részvételen és nyilvános vitán (deliberáción) kell alapulnia (Crocker [2008]). Az érintettek részvételén alapuló, egyedi utak biztosítják, hogy az emberi fejlődés céljának megfelelően az egyének képességei/lehetőségei oly módon bővüljenek, hogy közben befolyásolni is tudják a bővülés folyamatát (UNDP [2017]). A befolyásolási képesség társadalmi szintű megjelenése pedig a társadalmi részvételen keresztül értelmezhető (Rauschmayer és szerzőtársai [2011]).

A képességek/lehetőségek értékelése és a lista felépítése Nussbaum szerint elsősorban a filozófusok feladata, ám fontosnak tartja a több fronton jelentkező megvitatás szerepét is. Elsősorban a filozófusok közötti dialógust emeli ki, ők azzal a saját, kulturálisan sokféle tapasztalatukkal gazdagítják a megvitatást, amelyet az érintett csoportokkal való dialógusuk során szereztek (Nussbaum [2002]). Ezenfelül a rögzített képességek/lehetőségek a helyiek deliberációja által válik alkalmazhatóvá, a filozófiai dialógus pedig visszahat, hozzájárul a nyilvános, társadalmi deliberációhoz is. Nussbaum a saját munkásságában is e szerint jár el, listáját rendre felülvizsgálja a dialógusok hatására, és nyitva hagyja a lista további alakításának lehetőségét is (Crocker [2008]).

Sen szerint a saját életünk feletti irányítást akkor gyakoroljuk, amikor céljaink mellett megalapozott okokra hivatkozva elköteleződünk. Nem más dönt helyettünk, és kényszeríti ránk a választást, hanem mi magunk eldöntjük, hogy megvalósítjuk azokat, és véghez is visszük, vagy hozzájárulunk azok megvalósításához - vagy döntünk arról, hogy felhagyunk célunk véghezvitelével. Néha ezek a célok csak az egyén saját céljaihoz kapcsolódnak, néha mások céljaihoz, máskor pedig közös szándékokat is megfogalmazhatunk, és közösen is felléphetünk azok megvalósításáért. Minél teljesebben megfelel ezeknek a feltételeknek az egyén cselekvése, annál inkább képessé válik a saját ügyei tevékeny elömozditására (agency). Nussbaum a kontroll/irányitás (control) meglétén általában azt érti, hogy az egyén 
képes kialakítani önmaga számára az életről alkotott jó fogalmát, és kritikailag szemlélni azt, ahogyan saját életét tervezi (Crocker [2008]).

Sen és Nussbaum álláspontja sok ponton összekapcsolható. Mindketten a képességek/lehetőségek megteremtését helyezik előtérbe, tehát senkire sem kényszerítenek rá konkrét választásokat, azaz tevékenységeket/állapotokat (Nussbaum [2002], Sen [1999/2003]). Fontos számukra, hogy az egyének saját sorsukat aktívan befolyásolhassák, és erre képessé váljanak. Mindketten kiemelik a deliberáció szerepét. Máshová helyezik ugyan a hangsúlyt, de elmondható, hogy míg Sen tart attól, hogy felépítsen egy listát a képességekröl/lehetöségekröl, néhány mutatót (például az emberi fejlettség indexét [Human Development Index, HDI]) elfogad, empirikus munkája során megtesz bizonyos - a képességek/lehetőségek közötti - választásokat (AnandSen [1997], Stiglitz és szerzőtársai [2009]). Nussbaum pedig megadja ugyan a rögzített képességek/lehetőségek listáját, de egyrészt alakíthatónak tekinti azt, másrészt a közelmúltbeli listái egyre általánosabbak, így azok mindenképpen helyi (terepi) specifikációt igényelnek (Crocker [2008], Nussbaum [2011]).

Hogy az egyének mi alapján döntenek a jó fogalmáról, mi alapján választanak a képességek/lehetőségek között, mi számít megalapozott oknak, kritikainak, és mi az, ami már nem; milyen irányba terelhetik az életüket, és milyen irányba már nem - e nehéz kérdések visszaterelnek bennünket a képességek/lehetőségek halmaz kialakulásának kérdésköréhez. A képességszemlélet két fő megközelítésében a képességek/lehetőségek terének feltöltése, a lehetőségeink kiválasztása, a jó életről alkotott elképzelésünk, értékeink vagy szigorúbb esetben is azok pontosítása, specifikációja az egyén és az azt körülvevő közösség és társadalom interakciói által alakulnak.

A szegénység kérdésében az egyének, különböző társadalmi csoportok kapcsolata, a magunk és mások céljaihoz való hozzájárulás, a társadalom gyakorlati és intellektuális figyelme a jó élet kérdéséről kézzelfogható, hiszen a gyakorlatban a segítő szereplök különböző mértékben, de befolyásolhatják azt a folyamatot, ahogyan az érintettek céljainak, képességeinek/lehetőségeinek halmaza felépül. Empirikus kutatásomban bemutatom, hogy a helyi segítő folyamatok során ez a találkozás, együttmüködés milyen formát ölt a gyakorlatban, a segítői oldal milyen célok, értékek, szemlélet szerint tevékenykedik, s járul hozzá az érintettek lehetőségeinek alakításához.

\section{Módszertan}

A jelen kutatás a kvalitatív kutatások menetének megfelelően körkörös jellegü (Sántha [2011]), a kutatás teljes köre interpretatív, konstruktivista szemléletben folyt (Brinkmann-Kvale [2015]). 2017. január 31. és június 30. között 40 félig strukturált mélyinterjút folytattam le helyi segítő csoportok képviselöivel, beleértve civil szervezeteket (alapítványokat, egyesületeket), informális civil szerveződéseket, önkormányzati, állami egységeket, egyházközségeket, segítő tevékenységet is végző vállalkozásokat (vagy vállalkozási tevékenységet is végző szervezeteket). Az interjúk egyes résztvevői jellemzően egy-egy felsorolt kategóriához kapcsolódnak 
szorosabban, ám egyidejűleg más kategóriákhoz is tartozhatnak (lásd Függelék F1. táblázat). A kiválasztáskor a szervezeti forma helyett a segítő csoportok és egyének helyi aktivitásának ténye, érdemi jelenléte játszotta az elsődleges szerepet, de az előbbi tekintetében is fontos volt a sokféleség, és néhány jellegzetes eredmény kategóriák szerint is kirajzolódott.

Számos segítői tevékenységet folytató közösséggel, csoporttal - néhány egyetemi és civil szerveződésen keresztül - fenntartott kapcsolatom nyújtotta számomra az interjúkban részt vevők kiindulási bázisát. Az interjúkat követően az interjúalanyok sokszor maguktól, máskor kérésre további résztvevőket javasoltak a kutatáshoz (aktív szegénységenyhítő tevékenységet végző csoportokat vagy konkrét személyeket, akik lehettek vezetők, alkalmazottak vagy önkéntesek). A javaslatok alapján folyt a további résztvevők kiválasztása. A gondolatok fokozottabb ismétlődését (a telítettségi pontot $)^{7}$ a 27. és 30 . interjú között lehetett érzékelni intenzívebben bizonyos tématerületeken, ám az ezt követő interjúk során is gazdagodott újabb árnyalatokkal a kutatás.

A megkeresett személyek csupán három esetben nem vállalták az interjút. Egy esetben nem érkezett reakció a felkérésre, egy másik esetben nem szerettek volna részt venni a kutatásban, mert tevékenységük csak közvetetten kapcsolódik a gyakorlati szegénységenyhítéshez. A harmadik esetben a részvétel visszautasításának egyéb okai voltak. Két esetben a résztvevők ugyan jelezték, hogy tevékenységük esetleg csak közvetetten kapcsolódik a témakörhöz, de vállalták az interjút. A felkért résztvevők viszszajelzéseihez, javaslataihoz alkalmazkodva alakult ki a kvalitatív kutatásban részt vevők halmaza és határa - és egyben a szegénységenyhítési tevékenységek meghatározásának helyi értelmezése is, hiszen a felkérés során nem adtam számukra erre vonatkozó definíciót. Így az interjúk résztvevői maguk is mérlegelték saját relevanciájukat a gyakorlati szegénységenyhítés és a kutatásban való részvétel terén is (a kutató és az interjúk más résztvevőinek mérlegelésén túl).

Az interjúzás során a konstruktivista szemléletnek megfelelően aktív interjúzást választottam (Holstein-Gubrium [1995]). Eszerint a kutatásban részt vevők interpretációja az interjúzás gyakorlatán keresztül is alakul, a válaszadó és a kérdező egyenlő partnerekként alkotják meg a jelentést, a tudás teremtésében úgynevezett utazó interjú során közösen vesznek részt (Brinkmann-Kvale [2015]). A válaszadónak lehetősége van visszakérdezni, a kérdezőnek pedig - elkerülve saját interpretációjának előtérbe helyezését - helyben újraértelmezni azokat a válaszokat, amelyek esetleg nem egyértelmüek a számára (Brinkmann-Kvale [2015]).

$\mathrm{Az}$ interjú fonala öt fö témakörből épült fel:

1. az adott csoport/szervezet alakulása, az egyén és a csoport kapcsolódása;

2. a csoport tevékenysége, célja, küldetése;

3. a csoport müködését meghatározó tényezők (értékek, módszertan);

4. a csoport és a felkeresett egyén értékeinek kapcsolata, a csoporton belüli értékközösség és értékkülönbségek;

${ }^{7}$ Telítettségi pont: amikor az új interjúk kevés új tudást hoznak, nyújtanak az elözőkhöz képest, így az interjúzás folyamata hamarosan befejezhető (Brinkmann-Kvale [2015]). 
5. a csoport/segítők és az érintettek kapcsolata, beleértve a segítők és az érintettek értékeinek hasonlóságát és különbözőségét, az érintettek álláspontjának becsatornázási módjait, az érintettek elérését, a felek (segítő és érintett) közötti értékkülönbségek kezelését.

Ez az interjúfonál kiindulópontként szolgált, de az aktív interjúforma és a sokféle, egyedi tevékenység megismerése minden esetben fokozott koncentrációt és kontextusfüggő interjúmenetet kívánt meg. Az interjúk rögzítését minden résztvevő engedélyezte. A hanganyagot szó szerinti interjúleiratokká alakítottam, törekedve az elmondottak pontos leírására és a jelentősebb nonverbális jelek és események mellett a benyomásaim rögzítésére is.

Az elemzés során Brinkmann-Kvale [2015] elemzési technikái közül az ad hoc elemzési módszert alkalmaztam, azaz egy konkrét eljárás helyett a kutatási témakörhöz illeszkedő saját elemzési módot alakítottam ki. Az elhangzottakat a már ismert, továbbá az elemzés során ismertté vált kontextusban értelmeztem, azaz a szereplők perspektívája találkozott más interjúrésztvevők interpretációjával és az elemzőével is. Az elemzés során intrakódolást alkalmaztam, azaz többféle elemzési irányt is végigjártam. Az első irányban az interjúk egyenkénti elemzését, összefoglaló értelmezését végeztem el, a másodikban pedig az interjúkat 17, egymást nem kizáró kategória szerint rendeztem. A kiinduló kategóriák az interjúfonál kérdéseiből eredeztethetők, s néhány kategória még kiemelkedett az interjúkból. Ezt követően az irányok találkozásaként a jelentéstartalmak (Kvale [1996]) keresésére és összegzésére került sor. Mivel a szereplőknek anonimitást ígértem, így az eredmények bemutatása során sem egyéni, sem csoportszinten nem nevesítem őket.

\section{Eredmények}

Az eredményeket előbb három leíró, majd három elemző alfejezetben mutatom be (1. táblázat).

1. táblázat

Az eredmények bemutatása

\begin{tabular}{ll}
\hline Leíró alfejezetek & Kapcsolódó elemző alfejezetek \\
\hline A segítő tevékenységek módjai & A képessé tétel (empowerment) céljáról \\
Kapcsolódás az érintettekhez & $\begin{array}{l}\text { Az alapképességek/lehetőségek } \\
\text { meghatározásáról }\end{array}$ \\
Az interjúk résztvevőinek szemlélete & Az érintettek részvételéről \\
a szereplők értékeinek, céljainak találkozásáról & \\
\hline
\end{tabular}

Forrás: saját szerkesztés.

A leíró alfejezetekben az interjúkban elhangzottakat összegezem, majd az elemző alfejezetekben az elmélet segítségével is értelmezem azokat. 


\section{A segitő tevékenységek módjai}

Az érintettek és a segítők közötti együttmüködési lehetőségek közül a legmarkánsabban és a legtöbb tevékenységben megjelenő elem az adományozás, amely a legalapvetőbb szükségletek - többek között tüzifa, bútor, ruhaadományok, de kiemelten és elsősorban élelem - biztosítását célozza. A lakhatást és ruházkodást segítő adományok legtöbbször alkalomszerüen, szükségtől függően jutnak el az érintettekhez, az élelemadományok pedig többnyire folyamatosan elérhetők az év során. Az intenzív adományozási tevékenységből a civil szervezetek, szerveződések, az egyházközségek, az önkormányzati, állami egységek is jelentős részt vállalnak, sőt a helyi vállalkozások jórészt adományozás útján kapcsolódnak be a szegénységenyhítésbe.

Az interjúk alapján a segítői tevékenységek előzőknél kisebb mértékü, de meghatározó eleme az érintettek és segítők közötti beszélgetés, tanácsadás. Néhány esetben a kapcsolatok célja valóban erre korlátozódik, legtöbbször azonban a személyes kapcsolatok müködésébe beépülhetnek más tevékenységek is, amelyek a kapcsolatok és a szükség jellegétől függően lehetnek rendszeresek vagy alkalomszerủek, például: anyagi segítség, adományozás, különböző szolgáltatások biztosítása (ilyen a szállításban való segítség), az érintettek mobilitásának megkönnyítése, támogatás álláskeresésben, segítség a tanulásban. A személyes kapcsolatokban rejlö lehetőségek kihasználása mind a civil szervezetek, szerveződések, egyházközségek, mind pedig az önkormányzati, állami egységek sajátjai, bár az önkormányzati, állami egységek tevékenységére távolságtartóbb, érzelmileg semlegesebb kapcsolattartás jellemző.

A helyi szegénységenyhítési törekvésekben kisebb súllyal, de számottevően vannak jelen a tanulásban való felzárkóztatást célzó oktatási tevékenységek, elsősorban a gyermekeket érintő egyéni korrepetálások vagy tanodák formájában. E tevékenységek leginkább a civil szervezetek és szerveződések sajátjai.

A rendszeresen vagy alkalomszerủen biztosított pénzbeli támogatás csak egy-egy személyes kapcsolatra, civil szervezetre jellemzö, helyi szinten elsősorban valamely önkormányzati egység felel a pénzbeli támogatások elosztásáért.

Az említett segítői módok mellett jelen vannak még az érintettek számára szervezett közösségi programok, rendezvények és az érintettek foglalkoztatására való törekvések is, elsősorban közfoglalkoztatáson keresztül.

Az olyan programok, kezdeményezések, amelyek az érintettek alkotói készségére irányulnak (akár közös filmkészítés, közös mü írása, fotózás, zenélés, színmüvek elöadása és az ezeken keresztül történő pedagógiai vagy közösségfejlesztő jellegü foglalkozások), csak marginálisan jelennek meg a tevékenységek palettáján, leginkább civil szervezetek gondozásában.

A közösségszervezés mint segítői mód közvetetten és más tevékenységekkel átszőve jelenik meg. Egy-egy civil szervezet, szerveződés és jellemzően az egyházközségek sajátossága, hogy a közösség építésében rejlö lehetőségeket kívánják kiaknázni, ez azonban nem jelenti a közösségszervezés módszertanának alkalmazását. Annak követése, a közösségbe való közvetlen beépülés (a képessé tétel szándékával karöltve) csak egy-egy esetben - inkább csak egyfajta vágyként - fogalmazódott meg az interjúk során. Az ezzel kapcsolatos tapasztalat és tudás egyelöre korlátozottan áll 
rendelkezésre, néhány szereplőnél koncentrálódik, akárcsak az alkotói készségekre irányuló programok esetében.

Az érintetteket közvetlenül célzó módok mellett a gyakorlati segítést végzők között néhányan részvételiakció-kutatást, politikai érdekérvényesítést, társadalmitudatosság-növelést folytatnak, és/vagy elméleti kutatómunkát is végeznek. Azaz az ez irányú tevékenységekkel az érintetteken túl igyekeznek a társadalom más tagjait is elérni és formálni a társadalmi légkört. E tekintetben csak kisebb bázisról beszélhetünk, néhány kiemelkedően aktív szereplővel.

\section{Kapcsolódás az érintettekhez}

A szegénységenyhítési folyamatok során a különböző világok találkozásának első lépése - leszámítva egy-egy különleges megoldást, amikor is a felek nem lépnek közvetlen kapcsolatba egymással - maga az érintettekkel való kapcsolatfelvétel, az érintettek elérése.

Az állami, önkormányzati egységek esetében jellemzően az érintettek kereshetik fel a segítségforrást. ${ }^{8}$ A lehetőségeket, a támogatás módjait többnyire a nyomtatott sajtóban és interneten követhetik, illetve személyesen is részletes tájékoztatás érhető el az intézményekben, mivel sok érintett számára nem opció az internetes tájékozódás. Néhány civil szervezetre és szerveződésre is jellemző, hogy az érintettek keresik fel öket, és bárki részt vehet a programokon, de ez a lehetőség többnyire csak korlátozottan áll fenn. A legtöbb civil szervezetnek és szerveződésnek kialakult már az érintetti köre, az érintettek kiválasztása pedig leginkább a segítői oldalon dől el. Minden típusú csoportra jellemző, hogy az érintettek megkeresésekor korábbi kezdeményezésekre, programokra, már meglévő vagy más intézmények adatbázisaira támaszkodik. Néhány civil szervezet, szerveződés, egyházközség már meglévő személyes kapcsolatain keresztül próbálja elérni azokat, akiket a legnehezebb. Ök a „terepen” keresik fel az érintetteket, és próbálják átlépni a kialakult határokat. Az interjúk alapján számos oka lehet annak, hogy az érintettek kimaradnak a segítségböl.

- A szükséges segítői mód teljes egészében hiányzik, vagy a korlátozott kapacitás miatt abból nem részesül mindenki (például a női hajléktalanok számára rendkívül szűkösek az elhelyezési lehetőségek).

- A legeslegnehezebb helyzetben lévők a hivatalos információkat, felhívásokat nem vagy korlátozottan érik el; közintézményekben, új környezetben, társaságban nem mozognak magabiztosan, mobilitásuk nem magától értetődő.

- A kölcsönös szándék ellenére sem müködik az együttmüködés a segítők és az érintettek között. A bizalom kiépítése nagyon hosszú ideig tart, nem áll rendelkezésre az ehhez szükséges kompetencia, esetlegesen nem arra fordítódik, amire valóban

\footnotetext{
${ }^{8}$ Természetesen a jelzőrendszer is segíti a szegénységből (is) fakadó problémákról való értesülést az állami és önkormányzati egységek számára, ám az interjúk résztvevői szerint a szükséges jelzések megtétele sokszor elmarad, vagy túlságosan későn történik meg. Ennek egyik legfőbb oka a gyermekeket érintő esetekben, hogy a jelzést tevők (például iskolai, óvodai dolgozók) félnek a szülőkkel való konfrontációtól és annak következményeitől.
} 
szükség lenne az érintettek részéről (például olykor a szegénységenyhítés céljából elnyert pályázati pénzeket nem az érintettek igényei alapján költik el). Máskor már nem lehet segíteni az érintetteknek a helyzet mélységéből vagy a felek értékei közötti távolságból fakadóan.

- A szükség és a nélkülözés foka bizonyos mértékig átírja a segítés alapelveit, a képessé tétel (empowerment), az érintettek részvételének fontosságát (például szükséges az azonnali tűzifa- vagy ételadomány, függetlenül az érintetti hozzájárulás mértékétől).

- Nincs mindenkivel együttmüködési szándék a segítők részéröl, mert a segítők és érintettek értékei, normái és viselkedésjegyei közötti távolság a segítői megítélés szerint néhány esetben oly nagy, hogy valószínüleg már nem vagy csak nagyon nagy küzdelem árán lehetne áthidalni. Ilyen akadályt jelentenek például az érintettek körében a családon belüli hierarchikus viszonyok, a nőkkel és gyermekekkel szembeni családon belüli erőszak, a folytonos agresszió jelenlétének szintén családon belüli viszonylagos elfogadottsága vagy drogproblémák jelenléte.

- Az együttműködési szándék hiányzik az érintettek részéről. Ennek okairól az érintettekkel folytatott kutatás nyújthatna több információt. Az interjúkban részt vevők szerint azonban az elhatárolódás oka lehet, hogy sokan szégyellik a helyzetüket és életkörülményeiket. Teljes mértékben visszaszorulnak a saját környezetükbe, bizalmatlanok az emberekkel szemben, nehezen fogadják el a segítséget, vagy egyáltalán nem igénylik azt. Így nagyon sok probléma nem kerül felszínre, a legelszigeteltebben élők felkeresése pedig óriási kihívás és ellentmondásokkal terhelt.

- Elvétve megjelenik az a gondolat is, hogy vannak olyan érintettek, akik a segítségre nem érdemesek.

A segítők túlnyomó többsége mégis úgy véli, nem tehetők megkülönböztetések az érintettek között, és a fenti nehézségek ellenére mindenki számára segítséget kell nyújtani. Az elmondottak szerint ennek gyakorlati megvalósulása különösen nagy kihívás.

$A z$ interjúk résztvevőinek szemlélete a szereplők értékeinek, céljainak találkozásáról

Az érintettek részvétele a helyi segítő társadalomban alapvetőnek számít, fontosságát senki sem kérdőjelezi meg. Árnyalatnyi különbségek abban fedezhetők fel, hogy a részvétel során a szereplők szempontjai milyen súllyal esnek latba a célok kialakításakor. A segítők meglepően nagy része határozottan megfogalmazza, hogy amellett, hogy természetesen azért segít, hogy enyhítsen az érintettek nehéz helyzetén, tulajdonképpen semmit sem vár a tevékenységért cserébe, illetve ez az elvárás inkább egy távoli célként jelenik meg, és nem az érintettek értékrendjének megváltoztatására összpontosít. Mellérendelt kapcsolatról van szó, a meggyőzés helyett a választási lehetőségek bővítése, az érintettek saját útjukon való segítése a cél. Ez az attitűd nem csak a tisztán adományozási tevékenységek során van jelen, amikor közvetlenebb kapcsolatok a segítök és az érintettek között nem alakulnak ki. Több, az érintettekkel folyamatosan kapcsolatban álló csoport képviselője is hasonlóképpen gondolkozik. 
Ez a szemlélet így civil szervezetek, szerveződések, vállalkozások, egyházközségek és önkormányzati, állami egységek tevékenységét is jellemzi, többnyire függetlenül a szereplők közötti interakciók gyakoriságától.

A segítők szintén nagy része véli úgy, hogy mindkét fél értékrendje fontos az együttmüködési folyamatokban. Ez inkább az olyan tevékenységeknél értelmezhető, ahol a segítők - civil szervezetek, szerveződések, önkormányzati, állami egységek, egyházközségek - és az érintettek közötti interakció rendszeres vagy folyamatos, az együttműködés hosszú távon müködik (legyen az segítők és hajléktalanok, mélyszegények közötti együttmüködés vagy családsegítői folyamat).

A fenti szemléletekkel minden esetben karöltve és ugyan csak marginálisan, de bizonyos konkrét szituációkban felmerül a paternalista szemlélet szükségessége. Ekkor a segítők úgy vélik, a saját értékeik és normáik a követendők, és nem fogadható el minden különbség a szereplők értékei és normái között (például droghasználat, családon belüli elnyomás, erőszak, bünügyek felmerülésekor).

\section{A képessé tétel céljáról ${ }^{9}$}

A képességszemléletben az emberi fejlődés az egyének lehetöségeinek bővülését jelenti oly módon, hogy közben az egyének képessé váljanak saját ügyeik tevékeny elömozdítására (Sen [1999/2003], Crocker [2008]). A segítői törekvések számos formája müködik a kutatás helyszínén, az azonban szembeötlő, hogy elsősorban az adományokon keresztüli segítség esetén jött létre egy igen stabil hálózat, az adományozási elem sokszor más típusú tevékenységekkel átszőve is megjelenik. A képessé tételre törekvő segítői formák esetén néhány kiemelten aktív szereplö tevékenységét tapasztalhatjuk, a stabil hálózat e tekintetben azonban egyelöre alakulófélben van.

Ezek alapján a képessé tétel céljának explicit megjelenésére, a függőségi helyzet fokozatos csökkentésére, a módszerek árnyalására lenne szükség a helyi tevékenységek minden típusánál, az adományozások, anyagi támogatások, az erőforrások biztosítása esetén is. Számos olyan helyi tevékenység van, amelyekben célként jelenik meg az érintettek képessé tétele (például mentális segítség, oktatás, közösségszervezés, politikai érdekérvényesítés). E törekvésekre is érvényes, hogy a képessé tétel céljának folyamatos és időnkénti újbóli hangsúlyozása és a kapcsolódó, olykor függőség irányába ható elemek ellensúlyozása kiemelten fontos lenne.

A képessé tételi tevékenységek előtérbe helyezése természetesen nagyon nehéz, amikor az érintettek alapszükségleteikben szenvednek hiányt, azaz a létezésüket meghatározó feltételek sem állnak rendelkezésre hiánytalanul. Például az interjúk alapján - egyébként a nussbaumi univerzális képességekkel/lehetőségekkel szemléletesen párhuzamba állíthatóan - a mindennapjaikban életük, egészségük, akár testi integritásuk

\footnotetext{
${ }^{9}$ A képessé tétel (empowerment) kifejezés az önrendelkezés visszavételére, egy függetlenebb életre, az érintettek saját ügyeinek aktív alakítására, az életük feletti kontroll birtoklására való képessé tételre utal. A jövőben szükség lehet egy újabb kifejezésre, amely nem a segítők, hanem az érintettek perspektívájára, az egyén lehetőségeinek megnyílására (a fentiekre történő képessé tétel helyett az azokra való képessé válásra) összpontosít.
} 
veszélyben van (vagy másokat veszélyeztetnek), izolált, rideg környezetben élnek, szegregálódnak az életük több területén, hiányzik a közösséghez tartozás érzése, nem élik meg saját adottságaikat, tehetségüket; elnyomásban élnek, vagy másokat nyomnak el, lakhatásuk, ruházkodásuk, élelmezésük nem megoldott.

A szegénység állapotában számos kedvezőtlen tényező áll kölcsönhatásban egymással, amelyek újabb és újabb nehezítő körülményeket generálhatnak. A szegénységi csapdából való kilábalást bonyolítja a cselekvésre való képtelenség érzése, a problémákon való rágódás elvonja a figyelmet más tevékenységektől és a konkrét lépésektől (Mani és szerzőtársai [2013]), amelyek a jobb helyzethez hozzájárulhatnának. A hoszszú távú depriváció során az érintettek nagyon gyakran - többnyire tudat alatt lefaragják a személyes céljaikat, preferenciáikat egy mérsékeltebb, reálisabbnak tűnő szintre, létrejön egy túlélési stratégiára épülő mechanizmus, amely segíthet a nehézségekkel való megbirkózásban (Sen [1999/2003], Kozma [2003], Qizilbash [2012]). Sokszor az érintettek - szintén szenvedésüket és szomorúságukat enyhítve - nem úgy ítélik meg saját helyzetüket, mint egy külső szemlélő (Aldridge [2014]). Mások szerint a helyzethez való adaptáció nem mindig jár kéz a kézben a törekvések alacsony szintjével, illetve torzult észleléssel (Clark [2012a], [2012b]). E komplex szituáció felismerése, átlátása, a megfelelő segítség megfogalmazása és a tényleges cselekvés képessége nagy kihívás az érintettek és a segítők számára is.

\section{Az alapképességek/lehetőségek meghatározásáról}

Amartya Sen nem bocsát rendelkezésre egy előre meghatározott listát az univerzálisan érvényes képességekről/lehetőségekről, mivel az emberi természet összetett, az egyének pozíciói és értékelésük alapjai pedig mind nagyon egyediek lehetnek (Sen [1993], [2008]). Nussbaum viszont indokoltnak tartja, hogy az állam támogasson egy belső értékkel rendelkező listát, és törekedjen arra, hogy ezek a képességek/lehetőségek minden egyes ember számára elérhetők legyenek, attól függetlenül, hogy az egyéneknek milyen a jó életröl alkotott elképzelésük (Nussbaum [2006]).

A meghatározott képesség/lehetőség lista melletti érvek és az említett elméleti körülmények - mélyszegénység, permanens kognitív károsodás, különbözö társadalmi csoportok közösségi hagyományokban gyökerező elnyomása, kegyetlen preferenciák jelenléte - a segítők tapasztalatai szerint valóban felmerülnek a gyakorlatban is. Ezekben az esetekben a szabad választás lehetségessége, müködőképessége kérdéseket vet fel (Sen [1993], Nussbaum [2002], [2011], Crocker [2008]).

A szegénység állapotában a tapasztalatok alapján is gyakran megmutatkozhatnak olyan viselkedésjegyek, amelyek a legtöbb egyéni perspektívából szemlélve nem fogadhatók el egy társadalomban, nem képezhetik annak a lehetöséghalmaznak a részét, amelyből az egyének választhatnak (például az interjúk résztvevői által említett családon belüli elnyomás és erőszak, agresszív fellépés a környezettel szemben, prostitúció, bűnözés jelenléte). Janky [2016] alapján a strukturális tényezőkkel nehezen magyarázható viselkedési minták elismerése és jobb megértése az érintettek érdekeit szolgálja, és nem jelenti az érintettek hibáztatását helyzetükért. Viszont e társadalmi problémák 
közvetetten is tovább nehezítik az érintettek helyzetét, hiszen erősítik a közvélemény negatív hozzáállását a szegénységhez, s emiatt a társadalompolitikai döntések sok esetben nem kedveznek az érintettek számára.

Az elméleti és gyakorlati meglátások alapján is léteznek azok az esetek, amelyekben nem lehetséges, hogy az érintettek szabadon válasszanak, vagy ez az út nem tünik helyesnek. Az értékek, normák és a tényleges cselekvések alakítása viszont az egyik legmélyebb, legtürelmesebb együttmüködést kívánja meg a felek részéről. Ezt a rögös utat értelemszerủen kevesen vállalják magukra - függetlenül a szervezeti formától -, így ebben a helyzetben az érintettek teljesen és végérvényesen magukra maradhatnak az egymásra tornyosuló problémákkal, frusztrációkkal, számos olyan helyzetet (és elveszett embert) eredményezve, amelyben jelenleg a társadalom képtelen segítséget nyújtani. Az érintettek hibáztatása és a szituációk elrejtése helyett a mély helyzet elismerése és elfogadása, nyílttá tétele jelentheti a változás alapját.

\section{Az érintettek részvételéröl}

Amartya Sen szerint az érintettek részvételén alapuló, egyedi utak biztosítják, hogy az emberi fejlődés céljának megfelelően az egyén képességei/lehetőségei oly módon bővüljenek, hogy közben befolyásolni tudják az őket érintő folyamatokat (Sen [2008]). Bármely fejlesztési, szegénységenyhítési folyamatnak az egyén és a csoportok különböző kontextusának és eltérő céljainak megfelelően közösségi részvételen és deliberáción kell alapulnia (Sen [2000], Crocker [2008]). Nussbaum szerint a képességek/lehetőségek listáját a filozófusoknak kellene felállítaniuk több, más fronton megvalósuló dialógus mellett (filozófusok másokkal, érintettekkel történő párbeszéde, rögzített képességek/lehetőségek helyi specifikációja az érintettekkel történő dialógus során) (Nussbaum [2002], Crocker [2008]). Azaz a képességszemléletben bármely megközelítés szerint elengedhetetlen az egyes szereplök közötti megvitatás a szegénységenyhítés folyamatában.

Ennek ellenére a képességszemlélet olyan bírálatot is kap, amely alapján önmagában is rendelkezik paternalista jelleggel (Claassen [2014]). E szerint elkerülhetetlen, hogy néhány esetben a képességek/lehetőségek helyett a konkrét tevékenységek/állapotok támogatása kerüljön előtérbe (például a kognitív kapacitás hiányzik a mérlegeléshez, avagy néhány képesség/lehetőség - mint az egészség vagy biztonság - oly fontosak, hogy jogosnak érezhetjük a konkrét tevékenység/állapot támogatását, nem csak a képesség/lehetőség elérhetőségének biztosítását). Amikor paternalista módon járunk el, a személy szabad választását korlátozzuk, befolyásoljuk abból a célból, hogy az adott személy - szándékosan vagy akaratlanul - ne ártson magának (Claassen [2014]).

Az interjúk alapján elmondható, hogy a helyi segítői társadalom számára az érintettek részvétele és céljainak, értékeinek figyelembevétele természetes. Kizárólag a paternalista szemlélet alkalmazását önmagában senki sem tartja elfogadható stratégiának, de marginálisan, a már említett legnehezebb helyzetekben felmerül a létjogosultsága. Többnyire azonban a segítők jellemzően teljes mértékben elfogadják 
a másik fél normáit és céljait, vagy úgy vélik, hogy az együttműködésben mindkét fél normáinak fontos szerepe van, az érintettek igényeinek és az iránymutatásnak is. Az érintettek igényeinek figyelembevétele és a helyi segítői társadalom nyitott hozzáállása a részvétel tekintetében megalapozhatja a helyi segítő tevékenységek hosszú távú sikerességét.

\section{Következtetések}

Az emberi fejlődés elméletében és a képességszemlélet tárgyalásakor Amartya Sen és Martha Nussbaum megközelítését a képességek/lehetőségek rögzítésének kérdése alapján, annak két végpontján szokás értelmezni. Ez a kettősség és kizárólagosság elterelheti a figyelmet arról, hogy az egyes álláspontok kialakulását és relevanciáját milyen érvek támasztják alá, azok mögött milyen szándék és motiváció húzódik meg. Főbb következtetéseimet három pontban foglalom össze.

1. Sen és Nussbaum álláspontja elméleti szempontból nagyon sok tekintetben összeilleszthető. Mindketten a képességek/lehetőségek meglétét hangsúlyozzák. Fontos számukra, hogy az egyének irányítani tudják saját életüket. Mindketten kiemelik az érintettek részvételének elengedhetetlenségét. Sen a képességek/lehetöségek meghatározását teljes mértékben az érintettekre bízza, ugyanakkor bizonyos képességek/lehetőségek fontosságát elfogadja empirikus munkájában. Nussbaum rendelkezésre bocsátja a rögzített képességek/lehetőségek listáját, de a meghatározások általánosak, helyi specifikációt igényelnek, és tovább alakíthatók többfrontú megvitatás eredményeképpen.

2. A lefolytatott 40 mélyinterjú alapján elmondható, hogy a helyi szegénységenyhítő tevékenységek során a gyakorlatban szintén mindkét álláspont releváns. Akár a képessé tétel, a képességek/lehetőségek szabad választása vagy az érintettek részvétele tekintetében vizsgáljuk a gyakorlatot, egyértelműen kirajzolódik, hogy éppen a legnehezebb helyzetben élők esetében nagyon gyakran háttérbe szorulhatnak ezek az alapelvek a segítők és az érintettek közötti együttmüködés során - ha egyáltalán létrejön az együttmüködés. Ám ekkor csak a tünetek enyhítéséröl beszélhetünk, legtöbbször hosszú távon a segítö társadalom eröforrás és kompetencia hiányában nem tud - vagy csak nagyon-nagyon lassan tud - ezeken a helyzeteken változtatni. A változtatás szükségessége, szándéka azonban éppen ilyenkor a legfontosabb. Nagyon sok olyan szituációval állunk szemben, amelyet a jelenben nem tudunk érdemben kezelni, így az érintettek ebben az állapotban végképp magukra maradhatnak.

3. Az elméleti vizsgálódás és az empirikus eredmények is arra utalnak, hogy a nussbaumi és seni szemlélet közötti választás helyett azok összeillesztése, együttes országos és helyi szintủ adaptálása vihet közelebb e szélsőséges emberi állapotok érdemi alakításához. Ez azt jelentené, hogy az államnak célul kell kitüznie, hogy minden egyes állampolgára és lakója, a legeslegnehezebb helyzetben lévők számára is biztosítva legyenek az emberhez méltó élethez szükséges univerzális képességek/ lehetőségek. A két szemlélet részben a társadalmi gyakorlat különböző szintjeire 
vonatkozna, részben pedig összefüggne, találkozna egymással. A nussbaumi - vagy egy ahhoz hasonló - szemlélet alapján szükség lehet egy központi lista összeállítására (makroszinten) a képességekről/lehetőségekről. Ezek gyakorlatba ültetéséhez természetesen elengedhetetlen lenne a helyi szintü tevékenység, amelynek során már a seni és nussbaumi szemlélettel is összhangban (mikroszinten) a képességek/lehetöségek specifikációjára, helyi értelmezésére, a lehetőségekből történő szabad választásra kerülhet sor az érintettek céljainak, igényeinek megfelelően. Ha az emberi léthez szükséges központi képességek/lehetőségek biztosítására valódi szándék mutatkozna, akkor a helyi segítők gyakorlati tevékenysége során nagyobb tér nyílna a képessé tétel, a részvételiség elveinek, a képességek/lehetőségek szabad választásának figyelembevételére, hiszen a „tüzoltáshoz” (az alapvető feltételek biztosításához) szükséges kapacitás- és erőforrásigény terhe nem a helyi segítő egyéneknél és csoportoknál összpontosulna elsősorban. Az érintettek ebben az esetben kevésbé függnének a segítőiktől, a felek már az együttmüködés létrejöttéről is nagyobb mozgástérrel dönthetnének, ami partneri, horizontálisabb viszonyrendszerben valósulhatna meg, csakis ott, ahol arra valóban igény van.

Ez az elgondolás további pontosítást igényel. Mi az állam és mi a helyi segítők szerepe a szegénységenyhítési folyamatok során? Hogyan erősíthetik egymás hatékonyságát a szereplők és a szemléletek? Mi kerülhet és hogyan a képességek/lehetőségek halmazába? Mi történik akkor, ha valaki nem választja valamelyik lehetőséget a halmazból, holott az biztosítva lenne? Mikor és milyen típusú paternalizmusnak lehet - ha egyáltalán - létjogosultsága?

Számos opciónk van az iránymutatások, képesség/lehetőség listák közötti - akár ideiglenes - választásra. Az első számú pozitív lépés azonban annak a szándéknak a felvállalása és kimondása lenne, hogy a társadalmunkban minden egyes ember számára biztosítani kell a méltó emberi léthez szükséges feltételeket. Mindez alapul szolgálhatna arra, hogy legitim társadalmi vita kezdődjön a képességek/lehetőségek halmazáról, azok alakításának és megvalósításának módjairól. A szándék hiánya megnehezíti a körülményeket, ami bizonyosan visszahat minden egyes szereplö magatartására, a segítő tevékenységekre és azok fogadására is. A szegénység problémájának elodázása, láthatatlanná tétele, kriminalizálása az érintettek elszigetelődéséhez és az elöítéletek fokozódásához vezethetnek; az érintettek kiszolgáltatottabbakká válhatnak, a segítői tevékenységekben a hosszú távú partneri együttmüködések helyett szükségszerüen a sürgető problémák elhárításai kerülhetnek előtérbe.

A helyi segítő társadalom jelentős erőforrásokat és energiákat mozgat meg egy meglehetösen empatikus, toleráns és elfogadó közegben. Ahhoz azonban, hogy ez az attitüd és a konkrét gyakorlati tevékenységek hosszú távon is eredményesek legyenek, elengedhetetlen egy, az elörelépéseknek teret adó társadalmi környezet is, amelyben szándék mutatkozik a mélyszegénység felszámolására, az egyének bevonására az őket érintő társadalmi ügyekbe, a szociális tevékenységek elismerésére, értékelésére. A változások érdekében a szegénységenyhítési folyamatok összes szereplője közötti párbeszéd fokozására és a szegénységhez kapcsolódó kérdéseknek a jelenleginél sokkal több fronton történő, nyílt megvitatására lenne szükség. 


\section{Hivatkozások}

AldRIDGe, J. [2014]: Working with vulnerable groups in social research: dilemmas by default and design. Qualitative Research, Vol. 14. No. 1. 112-130. o. https://doi.org/10. 1177/1468794112455041.

Alkire, S. [2002]: Valuing Freedoms. Sen's Capability Approach and Poverty Reduction. Oxford University Press, New York, https://doi.org/10.1017/s0266267103231229.

Alkire, S.-Black, R. [1997]: A Practical Reasoning Theory of Development Ethics. Furthering the Capabilities Approach. Journal of International Development, Vol. 9. No. 2. 263-279. o. https://doi.org/10.1002/(sici)1099-1328(199703)9:2<263::aid-jid439>3.3.co;2-4.

Anand, S.-Sen, A. [1997]: Concepts of Human Development and Poverty. A Multidimensional Perspective. United Nations Development Programme, Poverty and Human Development. Human Development Papers, 1-20. o.

Brinkmann, S.-Kvale, S. [2015]: InterViews. Learning the Craft of Qualitative Research Interviewing. Sage Publications, Washington, DC.

Clatassen, R. [2014]: Capability paternalism. Economics and Philosophy, Vol. 30. No. 1. 57-73. o. https://doi.org/10.1017/S0266267114000042.

Clark, D. A. [2005]: The Capability Approach. Its Development, Critiques and Recent Advances. Department of Economics University of Oxford, http://citeseerx.ist.psu.edu/ viewdoc/download?doi=10.1.1.371.4189\&rep=rep1\&type=pdf.

Clark, D. A. [2012a]: Adaptation and Development. Issues, Evidence and Policy Relevance. Megjelent: Clark, D. A. (szerk.): Adaptation, Poverty and Development. The Dynamics of Subjective Well-Being. University of Manchaster, Palgrave Macmillan, Houndmills, 1-34. o. https://doi.org/10.1057/9781137002778.0006.

Clark, D. A. [2012b]: Adaptation: Implications for Development in Theory and Practice. Megjelent: Clark, D. A. (szerk.): Adaptation, Poverty and Development. The Dynamics of Subjective Well-Being. University of Manchaster, Palgrave Macmillan, Houndmills, 61-90. o. https://doi.org/10.1057/9781137002778_3.

Crocker, D. A. [2008]: Ethics of Global Development. Agency, Capability, and Deliberative Democracy. Cambridge University Press, New York, https://doi.org/10.1017/ cbo9780511492594.005.

DARvas ÁGNes [2015]: Gyerekszegénység. Vigilia, 80. évf. 11. sz. 813-821. o. http://epa.oszk. hu/02900/02970/00903/pdf/EPA02970_vigilia_2015_11_813-821.pdf.

Eurostat [2018]: 17 October: International Day for the Eradication of Poverty Downward trend in the share of persons at risk ofpoverty or social exclusionin the EU. But still around 113million people in this situation. Newsrelease, 159/2018. október 16. https://ec.europa. eu/eurostat/documents/2995521/9310033/3-16102018-BP-EN.pdf/16a1ad62-3af6-439eab9b-3729edd7b775.

FERGE Zsuzsa [2008]: Miért szokatlanul nagyok a magyarországi egyenlőtlenségek? Esély, 2. évf. 3-14. o.

GÉBERT JUdit [2015]: Mit is kell fenntartani? Fenntarthatóság a képességszemlélet perspektívájából. Közgazdasági Szemle, 62. évf. 9. sz. 972-989. o. https://doi.org/10.18414/ksz.2015.9.972.

GÉBERT JUdit [2017]: A képességszemlélet alapjai. Megjelent: Bajmócy Zoltán-Gébert JuditMálovics György (szerk.): Helyi gazdaságfejlesztés a képességszemlélet alapján. JATEPress, Szeged, 21-46. o.

Holstein, J. A.-Gubrium, J. F. [1995]: The Active Interview. Qualitative Research Methods, SAGE Publications, Inc. https://doi.org/10.4135/9781412986120. 
JANKY BÉLA [2016]: A szegénység újratermelődése. A struktúrától a kultúráig, és vissza. Gondolatok Orlando Patterson és Ethan Fosse „The Cultural Matrix: Understanding Black Youth” címü kötete kapcsán. Társadalomtudományi Szemle, 2. évf. 89-102. o. https://doi. org/10.18030/socio.hu.2016.2.89.

Kozma Judit [2003]: A szegénység pszichológiai vonatkozásai. Esély, 14. évf. 2. sz. 15-30. o. Kvale, S. [1996]: InterViews. An introduction to qualitative research interviewing. SAGE Publications, Thousand Oaks, Kalifornia.

Mani, A.-Mullainathan, S.-Shafir, E.-Zhao, J. [2013]: Poverty Impedes Cognitive Function. Science, Vol. 341. No. 6149. 976-980. o. https://doi.org/10.1126/science.1238041.

Nussbaum, M. [1993]: Non-relative Virtues. An Aristotelian Approach. Megjelent: Nussbaum M.-Sen, A. (szerk): The quality of life. Oxford University Press, New York, 242-270. o. https:// doi.org/10.1093/0198287976.003.0019.

Nussbaum, M. [2002]: Capabilities and social justice. International Studies Review, Vol. 4. No. 2. 123-135. o. https://doi.org/10.1111/1521-9488.00258.

Nussbaum, M. C. [2003]: Capabilities as Fundamental Entitlement. Sen and Social Justice. Feminist Economics, Vol. 9. No. 2-3. 33-59. o. https://doi.org/10.1080/1354570022000077926.

Nussbaum, M. [2006]: Human Functioning and Social Justice: In Defence of Aristotelian Essentialism. Megjelent: Koggel, C. M. (szerk): Moral Issues in Global Perspective. II. Human Diversity and Equality. Broadview Press, Ontario, 4-25. o.

Nussbaum, M. C. [2011]: Creating capabilities: the human development approach. Belknap Press of Harvard University Press, Cambridge, https://doi.org/10.4159/harvard. 9780674061200.

Qizilbash, M. [2012]: Utilitarianism, 'Adaptation' and Paternalism. Megjelent: Clark, D. A. (szerk.): Adaptation, Poverty and Development. The Dynamics of Subjective WellBeing. University of Manchaster, Palgrave Macmillan, Houndmills, 35-60. o. https://doi. org/10.1057/9781137002778_2.

RaUsChmaYer, F.-OMAnN, I.-FrüHmann, J. [2011]: Needs, capabilities and quality of life: refocusing sustainable development. Megjelent: Rauschmayer, F.-Omann, I.- Frühmann, J. (szerk.): Sustainable Development. Capabilities, needs, and well being. Routledge, New York, 1-24. o.

Robeyns, I. [2005]: The Capability Approach: a theoretical survey. Journal of Human Development and Capabilities, Vol. 6. No. 1.93-117. o. https://doi.org/10.1080/146498805200034266.

Robeyns, I. [2006]: The capability approach in practice. Journal of Political Philosophy, Vol. 14. No. 3. 351-376. o. https://doi.org/10.1111/j.1467-9760.2006.00263.x.

SÁntha Kálmán [2011]: Abdukció a kvalitatív kutatásban. Bizonytalanság vagy stabilitás? Eötvös József Könyvkiadó, Budapest.

Sen, A. K. [1993]: Capability and Well-Being. Megjelent: Nussbaum M.-Sen, A. (szerk.): The quality of life. Oxford University Press, New York, 30-53. o. https://doi.org/10.1093/0198 287976.003.0003.

SEN, A. K. [1995]: Inequality Reexamined. Cambridge University Press, Cambridge, https:// doi.org/10.1093/0198289286.001.0001.

SEN, A. K. [1999/2003]: A fejlődés mint szabadság. Európa Könyvkiadó, Budapest, 2003. Angolul: Development as freedom. Oxford University Press, Oxford, 1999.

SEN, A. K. [2000]: Consequential evaluation and practical reason. The Journal of Philosophy, Vol. 97. No. 9. 477-502. o. https://doi.org/10.2307/2678488.

SEN, A. K. [2008]: Capabilities, Lists, and Public Reason: Continuing the Conversation. Feminist Economics, Vol. 10. No. 3. 77-80. o. https://doi.org/10.1080/1354570042000315163. 
Stewart, F.-Deneulin, S. [2002]: Amartya Sen's contribution to development thinking. Studies in Comparative International Development, Vol. 37. No. 2. 61-70. o. https://doi. org/10.1007/bf02686262.

Stiglitz J. E.-Sen, A.-Fitoussi, J. P. [2009]: Report by the Commission on the Measurement of Economic Performance and Social Progress. Kézirat, https://ec.europa.eu/eurostat/ documents/118025/118123/Fitoussi+Commission+report.

UN [2015]: The Millennium Development Goals Report, 2015. United Nations, New York, http://www.un.org/millenniumgoals/2015_MDG_Report/pdf/MDG\%202015\%20rev\%20 (July\%201).pdf.

UNDP [2010]: Human Development Report, 2010. The Real Wealth of Nations: Pathways to Human Development. United Nations Development Programme, New York, https://doi. org/10.18356/e5a0500a-en.

UNDP [2017]: Human Development Report, 2016. Human Development for Everyone. United Nations Development Programme, New York, https://doi.org/10.18356/b6186701-en.

UTCAJOGÁsz [2018]: Megkaptuk a rendőrség fagyhalál-statisztikáit. Utcajogász Egyesület, Budapest, július 24. http://utcajogasz.hu/2018/07/megkaptuk-a-rendorseg-fagyhalalstatisztikait.

VÁRADI MónIKA [2015]: Szegénység, projektek, közpolitikák. Tér és Társadalom, 29. évf. 1. sz. 69-96. o. https://doi.org/10.17649/tet.29.1.2678.

\section{Függelék}

\section{F1. táblázat}

Az interjú résztvevőinek kategorizálása

\begin{tabular}{|c|c|c|c|c|c|}
\hline $\begin{array}{l}\text { Interjúk } \\
\text { sorszáma } \\
\text { (a lefolytatás } \\
\text { sorrendjében) }\end{array}$ & $\begin{array}{c}\text { Civil } \\
\text { szervezetek } \\
\text { (alapítványok, } \\
\text { egyesületek) }\end{array}$ & $\begin{array}{l}\text { Informális civil } \\
\text { szerveződések }\end{array}$ & $\begin{array}{l}\text { Önkormányzati, } \\
\text { állami egységek }\end{array}$ & $\begin{array}{l}\text { Egyház- } \\
\text { községek }\end{array}$ & $\begin{array}{l}\text { Segítő } \\
\text { tevékenységet } \\
\text { is végző } \\
\text { vállalkozások }^{\star}\end{array}$ \\
\hline 1. & + & + & & & \\
\hline 2. & & + & & & \\
\hline 3. & & + & & & \\
\hline 4. & + & & & & \\
\hline 5. & & & & & + \\
\hline 6. & & + & & & \\
\hline 7. & + & & & & + \\
\hline 8. & + & + & & & \\
\hline 9. & & + & & & \\
\hline 10. & + & + & & & \\
\hline 11. & & & & + & \\
\hline 12. & + & & & & \\
\hline 13. & + & & + & & \\
\hline 14. & & + & & & \\
\hline
\end{tabular}


Az F1. táblázat folytatása

\begin{tabular}{lcccc}
\hline $\begin{array}{l}\text { Interjúk } \\
\text { sorszáma } \\
\text { (a lefolytatás } \\
\text { sorrendjében) }\end{array}$ & $\begin{array}{c}\text { Civil } \\
\text { szervezetek } \\
\text { (alapítványok, } \\
\text { egyesületek) }\end{array}$ & $\begin{array}{c}\text { Informális civil Önkormányzati, } \\
\text { szerveződések állami egységek }\end{array}$ & $\begin{array}{c}\text { Egyház- } \\
\text { községek }\end{array}$ & $\begin{array}{c}\text { Segítő } \\
\text { tevékenységet } \\
\text { is végző }\end{array}$ \\
\hline
\end{tabular}

15.

16.

$+$

$+$

17.

18.

$+$

$+$

19.

20.

21.

22.

$23 .+$

$+$

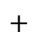

(1)

$+$

24.

25.

26.

27.

$+$

28.

29.

30.

$+$

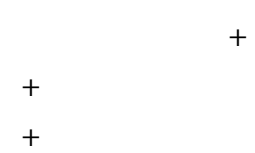

31.

32.

$+$

$+$

33.

34.

35.

$+$

36.

$+$

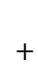

$+$

37.

38.

39.

$+$

$+$

$+$

$+$

40.

\begin{tabular}{llllll}
\hline Összesen & 18 & 12 & 10 & 6 & 6
\end{tabular}

*Vagy vállalkozási tevékenységet is végző szervezetek. 